\title{
Defensa por demencia en cargos de ofensa penal
}

Insanity Defense in Criminal Offenses Charges

Autor: Efrain Mendez Morales

DOI: https://doi.org/10.25058/1794600X.1039

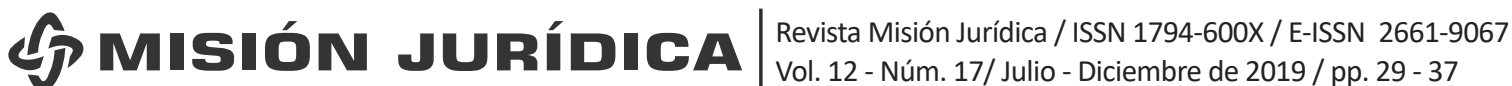




\title{
INSANITY DEFENSE IN CRIMINAL OFFENSES CHARGES*
}

\author{
Defensa por demencia en cargos de ofensa penal
}

Defesa da insanidade em acusações de crimes

Efrain Mendez Morales ${ }^{a}$ haley584@yahoo.com

Fecha de recepción: 6 de febrero de 2019 Fecha de revisión: 18 julio de 2019

Fecha de aceptación: 24 de julio de 2019

\begin{abstract}
The present written deals with the concept of liability, this is a legal term that is defined as the quality of a person to comprehend the consequences that will bring the voluntary performance of an unlawful act, and as such should be responsible, legally processed and liable for the act committed.

The medical expert witness in this type of case plays a vital role in the final decision that may carry the trial at the time of the verdict.

\section{KEYWORDS}

Liability, insanity, crime, responsibility, guilt, mentally disease, law, Not Guilty by Reason of Insanity (NGRI).

\section{* Artículo de reflexión}

a. A Bachelor Degree (BA) in Secondary Education Teaching of Chemistry from the InterAmerican University of Puerto Rico, Metropolitan Campus, San Juan, Puerto Rico. Completed in December 1995 with Distinction Magna Cum Laude. A Juris Doctor Degree (JD) from the Pontifical Catholic University of Puerto Rico, Ponce, Puerto Rico. Completed on May 2005 with Distinction Cum Laude. Mr. Efrain Mendez Morales, Esq. has been admitted to the following courts to practice the exercise of law: 1. Commonwealth of Puerto Rico, Supreme Court on August 29, 2006. 2. Federal District Court of Puerto Rico on February 07, 2008. 3. United States Court of Appeals for Veterans Claim on March 20, 2012. 4. Illinois Supreme Court on August 15, 2014. 5. Appellate Division of the Supreme Court of the State of New York, in and for the Third Judicial Department on August 10, 2016.
\end{abstract}




\section{RESUMEN}

El presente documento trata sobre el concepto de responsabilidad, término legal que se define como la calidad de una persona para comprender las consecuencias que traerá el desempeño voluntario de un acto ilegal, y como tal debe ser responsable, procesado legalmente y hallado legalmente responsable por el acto cometido.

El testigo médico experto en este tipo de casos juega un papel vital en la decisión final que puede llevar el juicio en el momento del veredicto.

\section{PALABRAS CLAVES}

Responsabilidad, demencia, crimen, culpa, enfermedad mental, ley, No culpable por razón de demencia (NGRI).

\section{RESUMO}

0 presente documento trata do conceito de responsabilidade, este é um termo legal que é definido como a qualidade de uma pessoa para compreender as conseqüências que trarão a execução voluntária de um ato ilegal e, como tal, deve ser responsável, processado e responsabilizado legalmente. pelo ato cometido.

A testemunha médica especialista nesse tipo de caso desempenha um papel vital na decisão final que pode levar o julgamento no momento do veredicto.

\section{PALAVRAS CHAVE}

Responsabilidade, insanidade, crime, responsabilidade, culpa, doença mental, lei, Não é culpado por razão de insanidade (NGRI).

\section{INTRODUCTION}

A criminal defendant who is found to have been legally insane when he or she committed a crime may be found not guilty by reason of insanity. In some cases, the defendant may be found guilty, but sentenced to a less severe punishment due to a mental impairment. However, we must take in mind that not all states in the United States allow the insanity defense in criminal cases.

In states that allow the insanity defense, the defendant must prove to the court that he did not understand what he was doing; that as consequence of his or her insanity failed to know right from wrong, and for that reason acted on an incontrollable impulse or some variety of these factors.

The first known recognition of insanity as defense to criminal charges was recorded in a 1581 English legal treatise stating that, "If a madman or a natural fool, or a lunatic in the time of his lunacy" kills someone, they cannot be held accountable. British courts came up with the "wild beast" test in the eighteenth Century in which defendants were not to be convicted if they understood the crime no better than "an infant, a brute or a wild beast". As we may see the test standard to determine is a person was insane or not, was an ambiguous appreciation of the court and by the knowledge that the person could present to understand the alleged committed crime.

Now a date, depending in the jurisdiction, courts use one or a combination of the following tests for legal insanity defense application:

- The “M'Naghten Rule": Defendant either did not understand what he or she did, or failed to distinguish right from wrong, because of a "disease of mind". Besides the fact that courts no longer use the terms "lunatic" or "wild beast", current laws allowing for the insanity defense follow a similar logic. The legal basis for insanity was codified into British law in the mid nineteenth Century with M'Naghten Rule, which is used in a majority of U.S. states and other jurisdictions around the world.

- $\quad$ The "Irresistible Impulse" Test: As a result of a mental disease, defendant was unable to control his impulse, which led to a criminal act. - The "Durham Rule": Regardless of clinical diagnosis, defendant's mental defect" resulted in a criminal act.

- The "Model Penal Code" Test for Legal Insanity: Because of a diagnosed mental defect, defendant either failed to understand the criminality of his acts, or was unable to act within the confines of the law.

The United States is a nation composed of fifty states, and territories which include Guam, Northern Mariana Islands and U.S. Virgin Islands and Puerto Rico.

A few states do not allow the insanity defense against criminal charges, including 
Idaho, Kansas, Montana and Utah. All four of these states, with the exception of Kansas, allow "guilty but insane" verdicts, which often provide for institutionalization instead of prison. Most states that recognize legal insanity use either the M'Naghten Rule, sometimes in combination with Irresistible Impulse Test or the Model Penal Code. Only the state of New Hampshire uses the Durham Rule standard.

The majority of states require the defense to prove that the defendant was indeed insane. However, there are some states where the prosecutor must prove that the defendant was sane at the time of been committed the crime. In states where the burden is on the defense to prove insanity, the defense is required to show either by clear and convincing evidence or by preponderance of the evidence that the defendant is insane. In states where the burden is still on prosecutors to prove sanity, they are required to prove it beyond reasonable doubt.

If a mentally ill defendant is found "not guilty by reason of insanity", it excuses that person from the legal responsibility for his or her criminal behavior, even though the person actually committed the crime. The insanity defense is rarely used, and in the few cases where it had been successful, the result is often the confinement of the individual to a mental institution, which may be as restrictive as imprisonment in the penal system.

\section{Discussion}

In the case of United States v. Hinckey, John W. Hinckey, Jr., who on March 30, 1981, shot President Ronald Reagan and three others, was found not guilty of attempted murder by reason of insanity. The trial led to significant amendments in the law regarding the insanity defense in criminal trials. In 1984, in direct response to the Hinckey verdict, the United States' Congress passed the Comprehensive Crime Control Act, which set a higher bar for the insanity defense in federal courts. This new statute established that lack of control was no longer a defense in criminal charges.

In the case of Texas $v$. Yates, Mrs. Andrea Yates drowned her five children in the bathtub of the family's home. At the trial in 2002, Yates' attorneys argued that she was insane, while the prosecution charged that she failed to meet Texas' definition of insanity because she was able to tell right from wrong. A jury found Yates guilty, rejecting her insanity defense, and she was sentenced to life in prison. In 2005, a Texas appeals court reversed the conviction and granted Yates a new trial after it was found that prosecution expert witness Dr. Park Dietz, a forensic psychiatric, gave erroneous testimony that influenced the jury. The appeal court demanded a retrial and on July 26, 2006, a jury found Yates not guilty by reason of insanity. This new law requires that the defense attorneys are the ones who must convince the judge or jury that their clients are insane, not the prosecutors have to convince that the defendant is sane. This new rule put the burden of prove of mental insanity over the defense and relief the prosecution to prove that the defendant is sane. According with this new legislation, every defendant is presumed to be mentally sane to face the judicial process against him or her.

A notorious case for the nineties decade was the serial killer trial of Jeffrey Dahmer which was celebrated in 1992. Mr. Dahmer originally pleaded not guilty, but later he changed his mind and pleaded guilty by virtue of insanity. During one of the hearing the expert witness of the defense, Dr. Judith Becker, who evaluated the defendant testified that he suffers from necrophilia and described with details how he killed the victims and had sex with the dead bodies and how the defendant removed the flesh from the victims' dead bodies, dried and conserved the skulls. The jury, however, was not convinced of Dahmer's insanity at the time that he committed the fifteen alleged crimes, so found him guilty on all charges, been sentenced to fifteen consecutive life terms in prison.

Many legal analysts expressed that the principal reason because Jeffrey Dahmer's insanity defense did not proceed or fail was because he remembered and described too many details of how he caught and killed his victims. He also described wisely the techniques he used to carve up the bodies. All these facts conducted the jury to conclude that he was sane at the time he committed the fifteen murders of all these men. They considered that the jury confused the ability of the defendant to understand the judicial process and the ability to contribute to his defense with the mental health of Mr. Jeffrey Dahmer at the precise time when he committed the crimes. It is mandatory to indicate that the defendant was a smart guy, fact that nothing has to do with his ability to control his emotional behavior. 
In 1840, Edward Oxford was charged with attempting the assassinate Queen Victoria and Prince Albert, but Oxford acquittal was based on the delusion test. The judge's words also went into legal history: "If some controlling disease was... the acting power within him, which he could not resist, then he will not be responsible." This reference to irresistible impulse has woven in and out of legal discourse ever since; the idea remains controversial to these days."

As we may see from the previous definition of what was considered mental ill or mental insanity as a defense in criminal cases has been always confuse and vaguely defined.

The first reasonable standard about the mental ill as a defense in criminal charges was identified in the case of Daniel M'Naghten. The insanity defense started and was elaborated in Britain with the case of M'Naghten of 1843. This famous case set the standard. The M'Naghten rule has evolved and been refined, but it provided the rule of insanity definitions in British law, and therefore in Canadian, North America and all other legal systems based on English law.

Going into the details of the Daniel M'Naghten case, we found that Mr. M'Naghten assassinated the secretary to Sir Robert Peel, the Tory prime minister, in an apparent case of mistaken identity. The intention of Daniel M'Naghten was to kill the prime minister himself, because, as he testified, Peel and his Tories had hounded him into financial and personal ruin, followed him everywhere, and accused him unjustly of crimes and wanted to murder him, all because he, a Scot, had voted against them in the last election.

The trial process was long and garnered enormous publicity. In the trial took participation nine well known medical witnesses, including a psychiatrist brought over from the United States, who declared M'Naghten insane, saying he had been acting under paranoid delusions at the time of the homicide. The verdict was Not Guilty by Reason of Insanity and Daniel M'Naghten spent the rest of his life in Broadmoor insane asylum.

The verdict pronounced provoked tremendous furor. Most of the public, the House of Lords and even Queen Victoria disagreed with verdict. This disagree caused that a panel of judges, including the Lord Chief Justice who had presided at the
M'Naghten trial, was soon brought together and under tremendous public and political pressure, worked out the stricter formula for determining the legal insanity of accused persons, and this became known as the M'Naghten standard.

The new paradigm provided four major rules. One, the accused is presumed sane and responsible until proven otherwise. Two, to be declared insane and hence not criminally responsible, the accused must, at the time of the crime, has been "laboring under such a defect of reason, from disease of the mind, as not to know the nature and quality of the act he was doing; or if he did, that he did not know what he was doing was wrong". Three, the accused is criminally responsible even when he believes he is redressing or revenging a nonexistent wrong or delusion for the public good if at the time of the crime, he knew he was acting contrary to criminal law. Four, the accused is not held responsible if the crime was a homicide that was a result or the delusion of the accused and acting in self-defense.

The M'Naghten case established another precedent by allowing expert testimony. Even though the final decision would still remain in the jury or judge, medical expert's testimony concerning the mental state of the accused at the time of the crime was henceforth admissible.

The mental insanity in our days is recognized in many countries in the world. However, it is still misunderstood or misinterpreted by the legal professionals and the general public.

In many countries, there continue to be conflicting opinions and mechanisms regarding the appropriateness of treatment and/or punishment for mentally ill individuals who commit crimes.

The citizens do not accept the idea that an individual who committed a crime does not is punished by his act. They still perceive erroneously that the measure of hospitalization as a way of avoid the prison and not a correct way to make justice to the victim. The courts have discretion to attend case by case and dictate the order, sentence or measure that they understand is correct to attend the situation presented before their attention.

The public is concerned with safety and of the finds are difficult to accept the possibility that 
a mentally ill individual who commits a crime, sometimes a serious crime, can be hospitalized and eventually discharged to the free community. The question of future risk that represents the individual can tip the scales in the direction of not releasing the patient from responsibility because of mental illness, even in situations when it might be appropriate. There are certainly cases in which mentally ill individual who commits a crime is sent to prison. For example, in 1999, a patient with a history of schizophrenia pushed a woman he had never met onto the New York City subway tracks in front of an oncoming train, causing her death. Previously, he had been discharged from the hospital against his will. The jurors determined mentally ill but guilty, because he understands the nature and meaning of his actions and because he told the police that he knew his actions were wrong.

Thus, some mentally ill individuals who do not receive appropriate treatment may eventually commit crimes that lead to involuntary hospitalization by court ruling. In addition, the option of potential responsibility in some countries leads to some prison time. In most countries, the options of incarceration and hospitalization are available in concert. While in some other countries, incarceration occurs before hospitalization, in other side, in some countries, hospitalization is first, followed by a prison term. In effect, this attitude can be described as a treatment/punishment ruling that integrated both concerns and contributes to public safety.

In the United States of America, the concept of guilty but mentally ill began in Michigan in 1975 and gained momentum following the case the United States v. Hinckley trial. Many states added this option to the insanity defense and did not abolish it. This verdict leads to a double stigma, and more prison time, because it implies that the accused committed the crime, was aware of the wrongfulness of the crime, but had a mental disorder that interfered with compliance of the law. The emphasis is on punishment and consideration of public safety and not psychiatric treatment in prison.

But for some history researchers, and according to the Historical Society of New York, the case of William Freeman was the first use of the insanity defense in the United States. In
1846, New York State processed in court William Freeman for slaying several members of the Van Nest family at their home near Auburn, New York. Mr. Freeman had been observed with false imprisonment for horse theft.

The case of William Freeman also includes the difference between the capacity of the defendant to face and understand the complex process of a trial and the mental state of the accused to understand the difference between right and wrong.

In the case of Commonwealth of Puerto Rico v. Campos Rodriguez, In the Court of Appeals, Judicial Regional Section of the City of Carolina Puerto Rico, In an Appellation from a Sentence of the First Instance Tribunal in the Case Number KLAN2011-0769 from September 14, 2012, the appellant-defendant who presented the defense of Temporary Mental Disorder (Trastorno Mental Transitorio) arguing that on the evening of August 10, 2010 she assassinated her two young kids, I. C. M. of 3 years old and Y.N. R. of 1 year old. Hitting them multiple stabs wounds and provoked a fire at the family home that caused burned in the left leg of Y.N.R. She was also accused of been used physical force and violence against his consensual partner, Y. R. R., and who was the father of her minor son, all this in presence of minors.

The public minister presented the testimony of the expert witness, Dr. Raul Lopez Melendez, who is a Forensic Psychiatrist. The expert evidence presented by the defense was a report and testimony of Dr. Carol M. Romey, Clinical Psychologist. The defense tried to rebate the presumption of mental sanity of the appellantdefendant and establish that she was not able to be find guilty for reason of been suffered a Temporary Mental Disorder at the moment that the events took place. In her report Dr. Romey concluded the following:

"During a brief period of time of approximately 5-15 minutes Coraly could be reacted to instigation to suicide from her partner or a toxic substance provided by him or another external cause out of her control that blinded her, caused a psychotic state, disorganized her conduct and took out her self-control during the time she committed the successes..." 
However, the expert witness presented by the District Attorney, Dr. Lopez Melendez, testified in court the following about the behavior of the appellant-defendant Campos Rodriguez:

"The expert witness described Coraly Campos Rodriguez of 21 years old, as a narcissist person with a pathologist personality who cannot stand a contrary opinion of others, who lost her control after argued with his sentimental partner and took effusive revenge with the terrible stabbing attack against her children of 3 and 1 years old". He also testified that the alleged voices that the defendant described in her testimony are " clinically inconsistent and do not follow the path of the majority of the auditory hallucinations» that have been studied." The expert distinguished between three types of mothers that assassinate their children: the mental ill mothers, the suicide mothers or the revenge mothers, category which he placed Coraly. He described this type of persons as one, "with problems of self-control", who when has problem with her sentimental partner discharge her fury against their children".

The defendant admitted that she killed her children, after a strong argumentation with her partner, who abandoned the house a little time before she assassinated the minors. Coraly attacked the children with a kitchen knife, after that, she stabbed herself in the stomach area and burned the house, but she left the bedroom with the injured kids when she felt the fire in her feet.

Dr. Lopez Melendez, who testified in court be trained by the expert witness of the case of Andrea Yates, in the United States, Dr. Phillip J. Resnick, denied that in the case of Mrs. Campos Rodriguez existed the same circumstances that in the case of Mrs. Yates, because in the case of Andrea Yates she had an historical record of psychosis and a mystical delirium at the time she killed her children. For this reason, the defense of temporary mental disorder did not progress in the court, and the defendant was found guilty of murders, domestic violence, the use of arm to commit a crime and deliberately had burned the family house. So the court imposed a sentence of more than 200 years in prison for the accused mother.

Dr. Phillip J. Resnick is an internationally known forensic psychiatrist noted for his expertise in the assessment of violence risk and the detection of malingered mental illness. He has provided consultation in many high profile cases including: Jeffrey Dahmer, Susan Smith, Timothy McVey, Andrea Yates, Scott Petersen, Brian Mitchell, Theodore Kaczynsky (Unabomber) and Casey Anthony. He has lectured in 49 states and 23 countries.

Another very notorious case was the James Eagan Holmes who was accused of killing 12 people and wounding 70 others at a movie theater in the city of Aurora in Colorado. This event happened the night of July 20, 2012. Holmes pleads not guilty by reason of insanity, and the court appointed two psychiatrists to conduct independent evaluations. In many states of the union, it is left to the defense to prove insanity, however in Colorado, the prosecutors bear the burden of proving suspect is sane. The prosecutors must show that the accused knew what he was doing was legally and morally wrong. Holmes avoided the death penalty and was incarcerated with a life sentence. His trial began on April 27, 2015 and on August 24, 2015 he was sentenced to 12 consecutive life sentences. The previous mental illness of Holmes was evident since he had been treated by a psychiatrist before the success in the theater in Aurora, Colorado.

\section{CONCLUSION}

The insanity defense is not used frequently, and by the other hand, in the most of the cases that it is presented, the verdict is against the defendant. Taking into account the facts found during this investigation, it is feasible to gather that most of the laymen and even the legal professionals who take part in the trial can become confused by the "technical words" used by the medical experts who participate as witness in these cases. It is not easy to be fully acquainted with medical terminology, especially when the person who possesses the expertise and dominion of these concepts does not take the awareness to explain them in a common language that the general public could understand clearly and what they mean in the deep content of the case and the fact under discussion. Terms as "disease", "defect", "irresistible impulse", "mental disorder", and other related to the mental state of a human being can result misleading or confusing for laymen.

It is necessary to make clear that the mental insanity defense is not applicable to every case which the accused or even his or her defense understands could progress. There is an 
important participation in the outcome of the case by the medical expert witness. It is also important to establish that is the court or the members of the jury who have in their hand the final decision. However, the insanity worked in a responsible, dedicate, and with the correct expert witness who know well what their role consist, who perform the correct evaluations and in a timely manner, could be presented either in a case before a jury or before a judge and the tip of the scale could be favorable to the defendant and to the society where the individual live. The final objective of the trial is to make justice, and it cannot be perceived that a human being who was not in an adequate state of mind at the moment of a crime and then is found as a mental insanity and the court order his hospitalization as a privilege or a failure of the justice system. It is necessary to remember, if by the other way, the person is send to prison without receive the adequate medical treatment; there still exist a great probability that the person commit another crime after his or her release.

Sometimes there are confusion about what types of mental disorders can potentially qualify for an "insanity defense, the well-defined and well-known illnesses such as schizophrenia are generally accepted, while other conditions as severe mood disorders, personality disorders and impulse control disorders fall into a called grey area. The degree to which any disorder affects the commission of the alleged committed crime by the accused also falls into the grey zone.
The insanity defense in the United States is used only in less than one percent (1\%) of criminal cases, and used successfully in only between ten to twenty-five percent (10 to $25 \%$ ) of these cases where it is claimed by the defense.

For those who are aware about that the accused with economical power could economically influence in the outcome of the evaluation and report of the psychiatry of psychologist who perform the evaluation, it is necessary to clarify that the prosecutor has the right to request that the defendant be evaluated by an expert of their selection and in some of the cases studied during this evaluation, the court also requested that the defendant be evaluated by another expert appointed by it, like happened in the case of Campos Rodriguez and others.

The term "insanity" is an ambiguous one. This word has no medical significance, as has been told by recognized authorities as described in the case of Sauer v. U.S., where it is used as a shorthand legal expression.

Medical professional and legal professional must work together to determine is an individual who committed a crime is sane or insane, all together in a legal court room to reach a final decision about the ultimate issue. This task is not easy taking in consideration that sometimes they have the pressure of the public and the media. 


\section{BIBLIOGRAPHY}

- American Psychiatric Association (2000). Diagnostic and Statistical Manual of Mental Disorders (4th ed., Text Revision). Washington, DC.

- Andersen v. United States, 237 F. 2d 118, (1956).

- Borum, R. and Fulero, S. (1999). Empirical Research on the Insanity Defense and attempted reforms. Evidence toward Informed Policy. Law and Human Behavior, 23(3), pp. 375-394.

- Callahan, L.; McGreevey, M.;Morrissey, J; and Steadman, H.(1993). Before and After Hinckley:Evaluating Insanity Defense Reform. The Guilford Press. pp. 15-112.

- Campos Rodríguez v. Pueblo de Puerto Rico, Tribunal de Apelaciones. Caso Número: KLAN2011-0769 (2012). [Translation by the author: Campos Rodriguez v. Commonwealth of Puerto Rico. Court of Appeals. Case Number: KLAN2011-0769. (2012)].

- Caplan, L., The Insanity Defense and the Trial of John W. Hinckley, Jr. (1984). pp.10125. Olympic Marketing Corp.

- Clark, R. (1995). Insanity and the Death Penalty. Capital Punishment UK. Retrieved from: http://www.capitalpunishmentuk. org/biblio.html

- Clark v. Arizona, 548 U.S. 735, 126 S. Ct. 2709 (2006).

- Comprehensive Crime Control Act, Public Law 98-473-October 12, 1984, 98 STAT. 1837.

- Congress wraps up a crime package. (1984). ABA Journal, 70(12), 44-46.

- Daubert v. Merrell Dow Pharmaceuticals, 509 U.S. 579 (1993).

- Delusion: a false belief that persists despite the facts and is common in some psychotic states. Webster's Intermediate Dictionary. G.\& C. Merriam Company, Publishers. Springfield, Massachusetts, U.S.A. 1977. Pp. 195.

- Durham v. U.S., 94 U.S. App. D.C. 228, 214 F. 2d 862 (1954).

- Hays, J. (2002). State of Texas v. Andrea Yates. Retrieved from The National Psychologist at: http://nationalpsychologist.com/2002/05/ state-of-texas-v-andrea-yates $/ 10608 . h t m l$

- Inderbitzin, R. (1969). Criminal Law-The ALI Model Penal Code Test. Lexis Nexis. Retrieved from: https://litigationewssencialts.lexisnexis. com/webcd/app?action=DocumentDisplay\&cra

- Jones v. U.S., 463 U.S. 354, 103 S. Ct. 3043 (1983).

- Fifth Amendment: "No person shall be compelled in any criminal case to be a witness against himself, nor be deprived of life, liberty, or property, without due process of law.." [U.S. Const. Amend. V].

- Fingarette, H. and Fingarette A. (1979). Mental Disabilities and Criminal Responsibility. pp.148-153.

- Foucha v. Louisiana, 112 S. Ct. 1780 (1992).

- Frederick, R.I. (2012). Insanity defense, diminished capacity mitigation. In D. Faust (Ed).Coping with psychiatric and psychological testimony: Based on the original work by Jay Ziskin (6th ed.)pp. 535-541. New York, NY, US. Oxford University Press.

- Freeman, 4 Denio 8 [sic] (1847). First use of the insanity defense in the United States. Available at: http://www.nycounts.gov/history-newyork/legal-history-eras-02/history-new-yorklegal-eras-people-freeman.html.

- Frendak v. U.S., 408 A. 2d 364 (1979).

- Garner, Bryan A; McDanel, Becky R; Schultz, David W. Black Law Dictionary. St. Paul, Minnesota, USA. Page 376. (5th ed. 1996).

- Goldstein, Abraham S., The Insanity Defense, (1967). pp. 100-179. Yale University Press.

- Insanity Defense Reform Act of 1984, Pub. Law No. 98-473, 98 Stat. 2057 (codified as amended at 18 U.S.C $\$ 4.01$ (1) (1962).

- Mathews, S and Kennet, J, (eds), (2004), Special Issue on "Responsibility and Mental Impairment." International Journal of Law and Psychiatry, 27:pp. 395-503.

- Melamed, Yuval, Mentally Ill Who Commit Crimes: Punishment or Treatment?, Journal of the American Academy of Psychiatry and the Law, March 2010, 38 (1), 100-103. 
- Melville JD, Naimark D: Punishing the insane: the verdict of guilty but mentally ill. Journal of American Academy of Psychiatry Law 30: 553-5, 2002.

- Moran, R. (1985). The Origen of as a Special Verdict: The Trial for Treason of James Hadfield. Law and Society Review. pp. 19, 487-519.

- M'Naghten's case, 8 Eng. Rep. 718, SEng. Rep. 722 (1843).

- Necrophilia, also known as necrophilism is a sexual attraction or sexual act involving corpses. Webster's Intermediate Dictionary. G.\& C. Merriam Company, Publishers Springfield, Massachusetts, U.S.A. 1977. It is classified as a paraphilia by the Diagnostic and Statistical Manual of Mental Disorders (DSM) of the American Psychiatric Association.

- Packer, I.K. (2015). Legal insanity and mens rea defenses. In B.L. Cutler and P.A. Zapf (Eds.) APA handbook of forensic psychology, Vol. 1: Individual and situational influences influences in criminal and civil context. Pp 87-114. Washington, D.C. US: American Psychological Association.

- Pub. L. 93-595, Jan. 2, 1975, 88 Stat. 1926, enacted the Federal Rules of Evidence proposed by the Supreme Court, with amendments made by Congress, to take effect on July 1, 1975.

- Rogers, Jeffrey L., et al, Insanity Defenses: contested or conceded?, 141 Am. J. Psychiatry 885,886 (1984).

- Rogers, R. and Shuman, D.W. (2000). Conducting Insanity Evaluations. (2nd ed.). pp.5-78. Guilford Press.

- SalizeHJ;Dreissing H: Placementand treatment of mentally ill offenders: legislation and practicein EU member states. Final report, February 15, 2005. Available at: http://ec.europe.eu/ health/ph_information/implement/wp/ mental/docs/ev_20050530_co04_en.pdf.

- Sauer v. United States, 241 F. 2d 640(9th Cir. 1957).

- Silva, J.; Ferrari, M. and Leong, G. (2002). The Case of Jeffrey Dahmer:Sexual Serial. Journal of Forensic Sciences, 47 (6).
- Steele, Scott (May 20, 1996), "Abbotsford Killer Arrested", Macleans. The Canadian Encyclopedia.

- Stanley Semrau, M.D. and Gale Judy, Murderous Minds on Trial (2001).Toronto. pp 24-66. The Dundurn Group.

- Terry, Zachary D; Billik Stephen B; Overlapping Universe: Understanding Legal Insanity and Psychosis (2010). Psychiatry Quarterly. DOI: 10.1007/ s11126-010-9134-2.

- The Andrea Yates case: Insanity Trial, Phillip J. Resnick. Western Reserve University, School of Medicine (2007).

- The Model Penal Code (MPC) is not law in any jurisdiction of the United States; however, it served and continues to serve as a basis for the replacement of existing criminal codes in over two-thirds of the states. Many states adopted portions of the MPC, but only states such as New Jersey, New York, and Oregon have enacted almost all of the provisions of it.

- The People of the State of Colorado v. James Holmes, 12CR1522.

- Turkewitz, J. (2015, July 9). Aurora Gunman Legally Insane, Psychiatrist Says. The New York Times. pp. A19.

- United States v. Hinckey, 529 F. Supp. 520 (1982).

- United States v. Hinckley, 672 F.2d 115(D.C. Cir. 1982).

- Waelder, R. (1952) Psychiatry and the Problem of Criminal Responsibility. University of Pennsylvania Law Review, 101 (3), pp. 378-390.

- Waldman A: (199, January 4).Woman killed in a subway station attack. The New York Times.

- Washington v. U.S., 129 U.S. App. D.C. 29, 390 F. 2d 444 (1967).

- Weiss, Kenneth J. and Gupta, Naha, Journal of the American Academy of Psychiatry and the Law. December 2018, 46 (4) 503512; DOI: http:// doi.org/10.29158/ JAAPL.003795-18.

- Yates v. Texas, 171 SW. 3 d 215, 222 (Tex. App. 2005). 